\title{
Гендерні особливості протеолітичної системи у хворих на мультирезистентний туберкульоз
}

Олещенко Г.П., Гнатенко І.А.

Сумський державний університет, м. Суми, Україна

Обґрунтування. Україна входить до десяти країн світу з найвищим тягарем захворюваності на мультирезистентний туберкульоз (МРТБ). Окрім цього, щороку зростає кількість хворих на МРТБ із первинною резистентністю. Останнє пов'язано зі збільшенням резервуару резистентної інфекції. Основними причинами цього $є$ недовиявлення близько 32 \% таких осіб і низька ефективність лікування виявлених хворих на МРТБ, а також слабко вивчені ланки патогенезу туберкульозного процесу.

Мета. Показати важливість подальших досліджень туберкульозу в Україні залежно від гендерних особливостей хворих.

Матеріали та методи. Було досліджено рівень нейтрофільної еластази (НЕ) в 37 хворих (25 чоловіків і 12 жінок), які мали МРТБ. Контрольна група становила 13 відносно здорових осіб - 9 чоловіків і 4 жінки. Активність НЕ в сироватці крові визначали за допомогою спектрофотометричного методу.

Результати та їх обговорення. Рівень НЕ в контрольній групі дорівнював 75,0 нмоль/Хв×мл, що було прийнято нами за нормальний показник. Серед хворих на МРТБ чоловіків рівень НЕ коливався від 19,5 до 272,2 нмоль/хв хмл і в середньому становив 110,9 нмоль/хвхмл. 3-поміж хворих на МРТБ жінок рівень НЕ коливався від 49,2 до 238,9 нмоль/хв хмл і в середньому дорівнював 98,9 нмоль/хвхмл. Отже, рівень НЕ був вищий за нормальний у хворих на МРТБ чоловіків приблизно в 1,5 раза $(110,9$ проти 75,0 нмоль/хвхмл). У хворих на МРТБ жінок рівень HЕ також був вищий за нормальний. Рівень НЕ у хворих чоловіків був вищий, аніж у хворих на МРТБ жінок $(110,9$ проти 98,9 нмоль/хвхмл). Тобто активність НЕ серед обох гендерних груп була вищою за нормальну, проте хворі на МРТБ чоловіки мають майже в 1,5 раза вищу активність HE, ніж жінки.

Висновки. Ці показники можуть свідчити про те, що у хворих на МРТБ чоловіків специфічний процес перебігає із залученням більшої активності компенсаторних сил як відповідь на агресивніший вплив резистентного збудника на чоловічий організм. 